\title{
MORPHOLOGICAL FEATURES \\ AND FORMATION CONDITIONS OF THE ALMOPIA SPELEOPARK CAVES (LOUTRA ALMOPIAS, N. GREECE)
}

\author{
MORFOLOŠKE ZNAČILNOSTI \\ IN POGOJI NASTANKA JAM V SPELEOPARKU ALMOPIA \\ (LOUTRA ALMOPIAS, SEVERNA GRČIJA)
}

\author{
Georgios LAZARIDIS ${ }^{1, *} \&$ Vasilios MELFOS ${ }^{2}$
}

\begin{abstract}
UDC 551.435.84(495)

Georgios Lazaridis \& Vasilios Melfos: Morphological features and formation conditions of The Almopia Speleopark caves (Loutra Almopias, N. Greece)

The Almopia Speleopark caves are located at the Almopia basin in northern Greece, at the foothill of Voras Mountain, and are formed in the Maestrichtian limestones of the Pelagonian zone. They are studied on the basis of their meso- and microscale morphology as well as their horizontal pattern, in order to investigate the character of the forming aquifer. Emphasis is given on the morphological description of the Loutra Almopias Cave. Cave morphology is dominated by the presence of cupolas, rock bridges, ridges and "windows", abrupt terminations of fracture guided passages, pendants, rising channels, pseudonotches, false-floors and spongework. Speleogens indicate a speleogenesis due to slowly natural convecting hot water bodies. Phreatic calcite from the Varathron Cave is analyzed on the basis of the fluid inclusions in order to investigate the physicochemical conditions of the convecting water bodies. This has shown that the calcite was formed at temperatures ranging between 120 and $189{ }^{\circ} \mathrm{C}$, with a peak around $150{ }^{\circ} \mathrm{C}$. The fluids were dominated by $\mathrm{NaCl}$ of very low salinities (0.2$1.0 \mathrm{wt} \% \mathrm{NaCl}$ equiv.), showing probably the incorporation of meteoric waters.

Key words: Phreatic calcite, thermal water, hypogene speleogenesis, hydrothermal cave, Loutra Almopias Cave, Greece.
\end{abstract}

Izvleček

UDK 551.435.84(495)

Georgios Lazaridis \& Vasilios Melfos: Morfološke značilnosti in pogoji nastanka jam v speleoparku Almopia (Loutra Almopias, severna Grčija)

Speleopark Almopia je ob vznožju gore Voras v porečju Almopije v Severni Grčiji. Jame so nastale v maastrichtskih apnencih Pelagonske cone. $\mathrm{Z}$ analizo jamskih skalnih oblik in tlorisov jam smo raziskovali pogoje njihovega nastanka. Največ raziskav smo naredili v jami Loutra Almopias. Med oblikami so značilne kupole, skalni mostovi, skalni grebeni, okna, nezvezni zaključki rovov nastalih ob razpokah, dvigajoči se kanali, lažne korozijske zajede in tla ter prepleti drobnih kanalov. Iz skalnih oblik sklepamo, da so jame nastale s korozijo počasnih konvekcijskih tokov termalne vode. Fizikalno-kemične pogoje speleogeneze smo določali $\mathrm{z}$ analizo tekočinskih vključkov $\mathrm{v}$ freatičnem kalcitu iz jame Varathron. Temperatura izločanja kalcita je bila med $120^{\circ} \mathrm{C}$ in $180^{\circ} \mathrm{C}, \mathrm{z}$ vrhom temperaturne porazdelitve pri $150^{\circ} \mathrm{C}$. Nizka slanost tekočinskih vključkov, masni delež soli je med $0,1 \%$ in $1 \%$, kaže da tekočinske vključke sestavlja pretežno meteorna voda.

Ključne besede: freatični kalcit, termalna voda, hipogena speleogeneza, hidrotermalna jama, Loutra Almopias, Grčija.

\footnotetext{
1,2 Faculty of Geology, Aristotle University, Thessaloniki, GR-54124, Greece, geolaz@geo.auth.gr

* Corresponding author
} 


\section{INTRODUCTION}

The Almopia Speleopark comprises a group of caves with geological, paleontological and archaeological interest. The so-called "Bear Cave" (Loutra Almopias Cave, former name Loutra Arideas Cave) is important due to a collection of more than 15,000 specimens of large mammals recovered during excavations since 1992 (Tsoukala \& Rabeder 2005). Most of the material is attributed to Ursus ingressus (Rabeder et al. 2004). The associated fauna includes spotted cave hyena, cave lion, leopard, wolf, fox, badger, mustelids and artiodactyls of Late Pleistocene age (Tsoukala 1994; Tsoukala et al. 1998, 2001; Tsoukala \& Rabeder 2005; Pappa et al. 2005; Tsoukala et al. 2006). Additionally, many thousands specimens of micromammals have been identified (Chatzopoulou et al. 2001).

Since 1990, when the first explorations took place in the Speleopark, more than ten caves and shelter caves have been recorded. In 2004, a new effort begun, aiming in interpreting the speleogenesis of these caves through detailed morphological and mineralogical investigations on the basis of a resurvey (Lazaridis 2005). The study of these caves is part of a broader on- going research on hypogene caves and speleogenesis in Greece (Lazaridis 2017).

In previous works two development phases of the caves were distinguished based on their morphology. The main phase took place in deep-seated conditions by a slowly convecting and upwelling thermal water body, while in the second one surface water, which entered the caves, re-sculptured the walls of some cave passages under turbulent flow conditions (Lazaridis 2006). Furthermore, hypogene speleogenesis is also known from the Provalata Cave in North Macedonia (Temovski et al. 2013; Temovski 2017).

The aim of the present study is to define the conditions under which the main phase of speleogenesis took place on the basis of the cave morphology at Varathron Cave, and to determine the physicochemical conditions forming the phreatic speleothems (cave clouds) in the context of the fluid inclusion data. Furthermore, a detailed description on the dissolution morphology of the Loutra Almopias Cave is presented and discussed.

\section{GEOLOGICAL SETTING}

The Speleopark is located at the Almopia basin in northern Greece, at the foothill of Voras Mountain (Kato Loutraki village). The area under study belongs to the Pelagonian zone of the Hellenides and is situated not far from the geological boundary with the Almopia zone (Fig. 1). The area consists of alpine metamorphic rocks, Mesozoic carbonates and flysch deposits of Upper Cretaceous-Palaeocene age. Volcanic rocks of intermediate composition and high potassium character intrude the Almopia zone (Vougioukalakis 2002). The volcanic activity is dated between $5 \mathrm{Ma}$ (million years) at the eastern and $1.8 \mathrm{Ma}$ at the south-eastern part of the Voras Mountain (Kolios et al. 1980). The caves were formed in the Maestrichtian limestones of the Pelagonian zone. Geological formations are dominated tectonically by the ENE-WSW striking Loutraki Fault and the NNW-SSE striking overthrust of Almopia zone onto the Pelagonian (Fig. 1). Ore-bearing faults (filled with pyrite, Mn- and Fe-oxides) occur north and north-west of the Kato Loutraki village (Mountrakis 1976). The Loutraki Fault bounds the Voras Mt. against the Almopia basin, which is due to the Neogene extensional tectonic regime (Chatzidimitriades 1974; Mountrakis 1976; Eleftheriadis 1977).

Three uplifted denudation surfaces of Neogene age and two piedmont surfaces of Villafranchian-Villanyian or Pleistocene age had been referred by Psilovikos \& Kanetsis (1989) at the northern part of the Pelagonian zone. These uplifted movements resulted in the down-cutting erosion of the Thermopotamos River that flows through the Almopia Speleopark area.

Numerous $\mathrm{Ca}-\mathrm{Mg}-\mathrm{HCO}_{3}$ hot springs with a temperature of $37^{\circ} \mathrm{C}$ are found in the Almopia Speleopark area and are probably related to the volcanic activity of the Pliocene (Dimopoulos 1990; Patras 1990). 


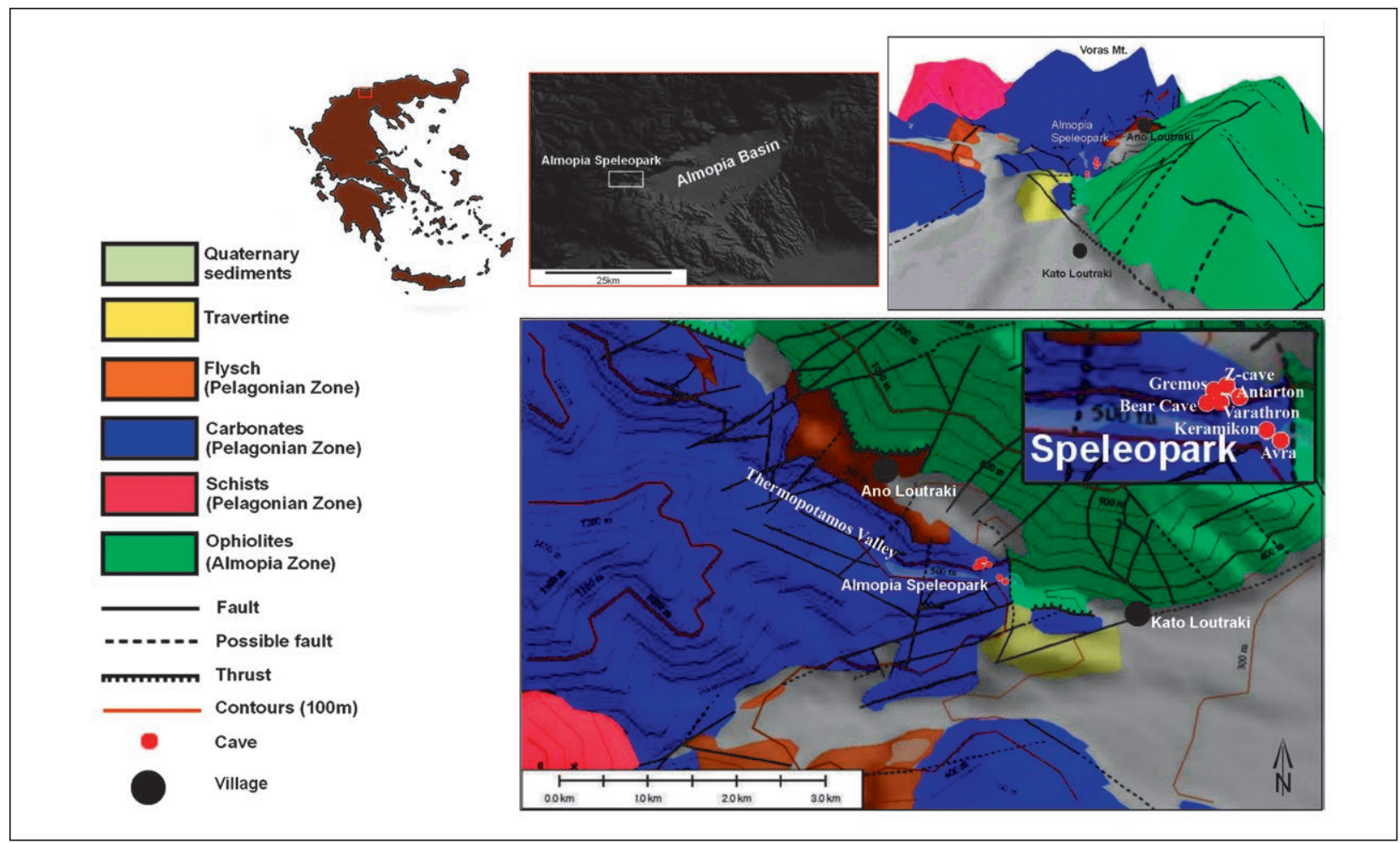

Fig. 1: Geological sketch-map of NW Almopia Basin (based on Mercier et al. 1988); inset maps: Greece with the Almopia Basin depicted (upper left corner); Almopia Basin and Speleopark (upper middle); 3D view of the geology of the Almopia Speleopark broader area (upper right corner, vertical exaggeration 1.5).

\section{METHODS}

Investigation of speleogenesis processes that formed the caves is done with detailed survey of the caves interior and underground small- and medium-scale geomorphological features. In particular the identification of hypogene speleogenesis (see Palmer 2000, 2007; Klimchouk 2007, 2009, 2016; Dublyansky 2013, 2014; Klimchouk et al. 2017) is based on a number of criteria proposed and discussed in a number of papers (e.g., Klimchouk, 2007; Audra et al. 2009a, b; Dublyansky 2013; Klimchouk et al. 2014; De Waele et al. 2016). Cave morphology is examined on the basis of the horizontal cave pattern (Palmer 2000, 2005) and by recognizing specific mesoand micro-scale morphology in cave passages (Kempe et al. 1975; Bögli 1978; White \& Deike 1989; Lauritzen \& Lundberg 2000; Lundberg 2005; Klimchouk 2007), in order to investigate the character of the host aquifer (Ford, 2000; Klimchouk, 2007). Basic terminology is given in Fig. 2. Morphometrical parameters are calculated according to Klimchouk (2007) and Lazaridis (2009).

The calcite samples collected from the Varathron Cave were studied by optical microscopy at the Department of Mineralogy, Petrology, Economic Geology, Aristotle University of Thessaloniki, for the determination of

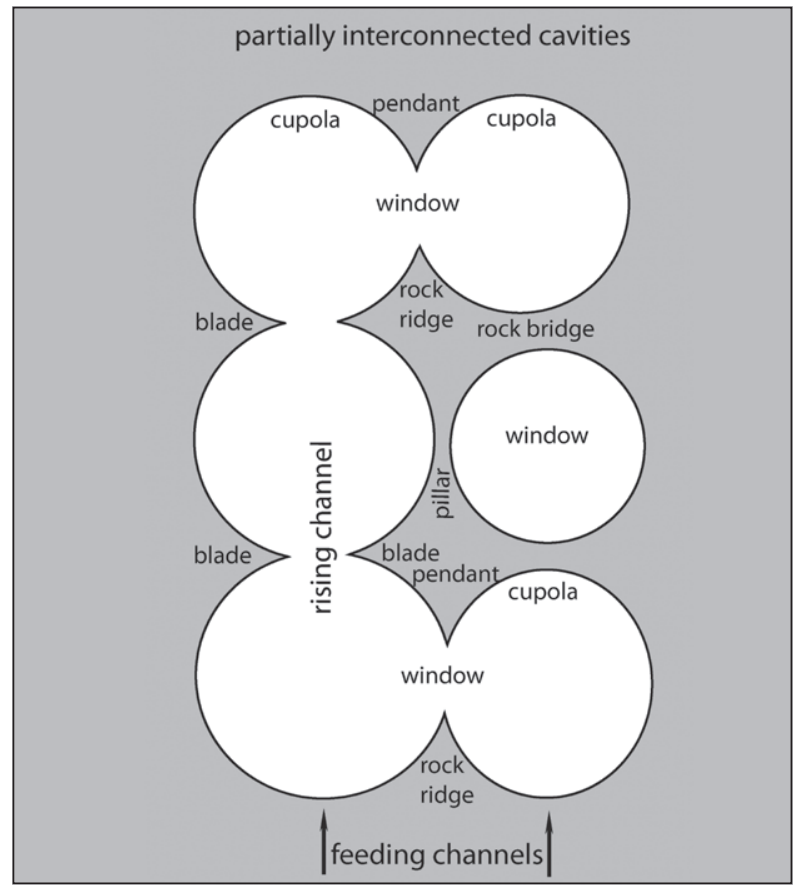

Fig. 2: Sketch showing basic geomorphological features and terminology used in text. Earlier stage of development is dominated by isolated adjacent cavities that become interconnect with dissolution progress. 
the constituent minerals, their texture and the grain size. In addition powders of the samples were analysed by $\mathrm{X}$ ray diffraction (XRD) in order to distinguish calcite from aragonite or dolomite.

Microthermometric data were obtained using a LINKAM THM-600/TMS 90 heating-freezing stage coupled to a Leitz SM-LUX-POL microscope, housed at the Department of Mineralogy, Petrology, Economic Geology of the Aristotle University of Thessaloniki. Calibration of the stage was achieved using organic standards with known melting points (chloroform $-63.5^{\circ} \mathrm{C}$, naph- thalene $80.35{ }^{\circ} \mathrm{C}$, Merck $135135^{\circ} \mathrm{C}$, saccharine $228^{\circ} \mathrm{C}$, Merck $247247^{\circ} \mathrm{C}$ ) and ice $\left.\left(\mathrm{H}_{2} \mathrm{O}\right)\right)$. The precision of the heating and freezing measurements were $\pm 1{ }^{\circ} \mathrm{C}$ and \pm 0.2 ${ }^{\circ} \mathrm{C}$, respectively. Fluid inclusion shapes and sizes, spatial relationships among inclusions and minerals and phases within inclusions were observed in three doubly-polished thin sections prepared at the University of Hamburg, Germany. Routine heating-freezing runs were performed on a total of 79 fluid inclusions. The FLINCOR program (Brown 1989) was used to process the fluid inclusion data for calculating salinities and densities.

\section{MORPHOLOGY OF THE ALMOPIA SPELEOPARK CAVES}

Almopia Speleopark caves are of spongework horizontal pattern and network mazes or a combination of both patterns. Especially the caves of the northern slope of the Thermopotamos valley are of spongework pattern in contrast to the network caves of the southern slope. Cave passages are fracture guided and of elliptical shape. In various places assemblages of circular, in cross section, passages that developed along fractures or bedding planes, form boneyard morphology (e.g., Antarton Cave). Cave passages are commonly abruptly terminated ("blind" passages).

Meso- and micro-scale cave morphology is dominated by cupolas, feeders, fissure-like feeders and side-wall feeders, pendants, rock bridges inside chambers and passages, rock ridges that separate chambers, pseudonotches (sensu Osborne 2004), "windows" that connect chambers, in some cases flat passage ceilings, and wide wall pockets flattened upwards. Network mazes present the same speleogens except those formed in chambers, such as "windows", rock bridges and bedrock ridges. Exceptionally, in some cave passages scallops and false floors are formed, due to the above-mentioned second phase of development. The alteration of the original cave morphology by dissolution in the vadose zone is very limited.

Cave morphology strongly indicates phreatic speleogenesis in deep-seated setting by slowly convecting water bodies. However, scallops, detritus sediments, eroded deposits and false-floors represent invasion by surface water (Thermopotamos Stream). This second phreatic event followed the main cave development after the uplifting movements of the mountain and the cave drainage.

Apart from the speleogens, in an inclined passage of the Varathron Cave calcite formations were found that indicate phreatic origin and they are strongly related to the first phreatic event that developed the caves. This deposit covers the perimeter of the cave passage forming in some places cave clouds and is analyzed on the basis of the fluid inclusions in the present paper in order to investigate the physicochemical conditions of the convecting water bodies.

\section{DETAILED SOLUTIONAL MORPHOLOGY OF THE LOUTRA ALMOPIAS CAVE}

The Loutra Almopias Cave is located at the northern slope of the Thermopotamos Valley. The two-dimensional morphometrical parameters of the cave are (Fig. 3): cave area $810 \mathrm{~m}^{2}$; passage length: $\sim 250 \mathrm{~m}$; area of cave field: $1470 \mathrm{~m}^{2}$ (polygon method, Klimchouk 2007); passage density $168 \mathrm{~km}^{-1}$; areal coverage: 55\%; V1-score (sensu Lazaridis 2009): -20.69. The limestone is dipping toward the NW. The cave entrance is developed due to valley collapse at $540 \mathrm{~m}$ above sea level, having no relation to the recent topography. The cave floor at the entrance is about $2 \mathrm{~m}$ higher than inside the cave due to collapsed boulders. The entrance chamber shows spongework dissolu- tion pattern at the ceiling, a rock bridge and a "window" to the northern part and a pillar that separates a parallel gallery to the rock bridge passage (indicative morphological features from all cave chambers are given in Fig. $4 \mathrm{a}-\mathrm{g})$. Blind passages are also present as well as to the rest of the chambers.

Two NE-SW striking passages connect the entrance chamber with the first chamber of the cave (LAC I). The northern one is a narrow and high passage that terminates to bedrock ridges at both ends, which probably constituted a fissure-like feeder (Fig. 5a). The cave floor is about $3 \mathrm{~m}$ lower than the entrance chamber and 


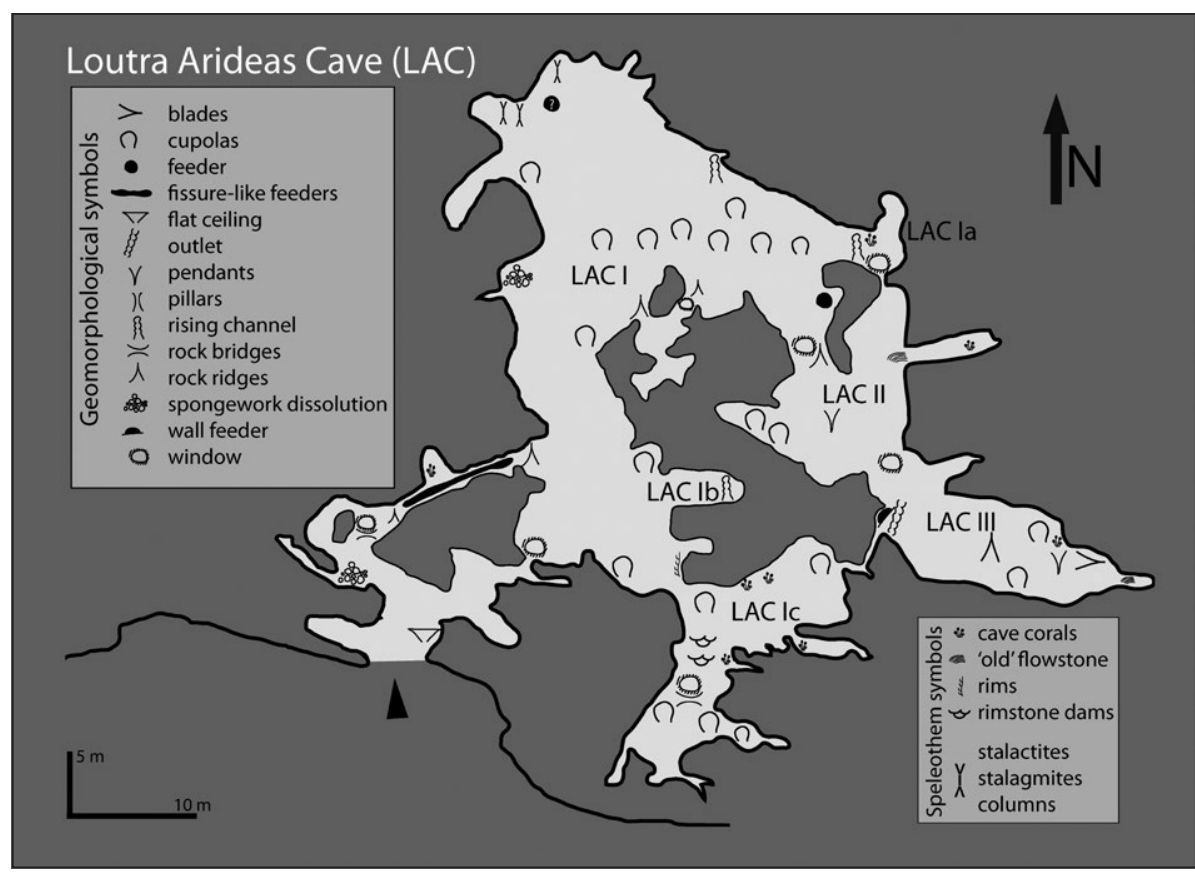

Fig. 3: Geomorphologic sketchmap of the "Bear Cave". Cave outline modified after Kampouroglou \& Chatzitheodorou 1999. Cupolas are distributed in the whole cave area and only some main features are depicted on map for better appearance.

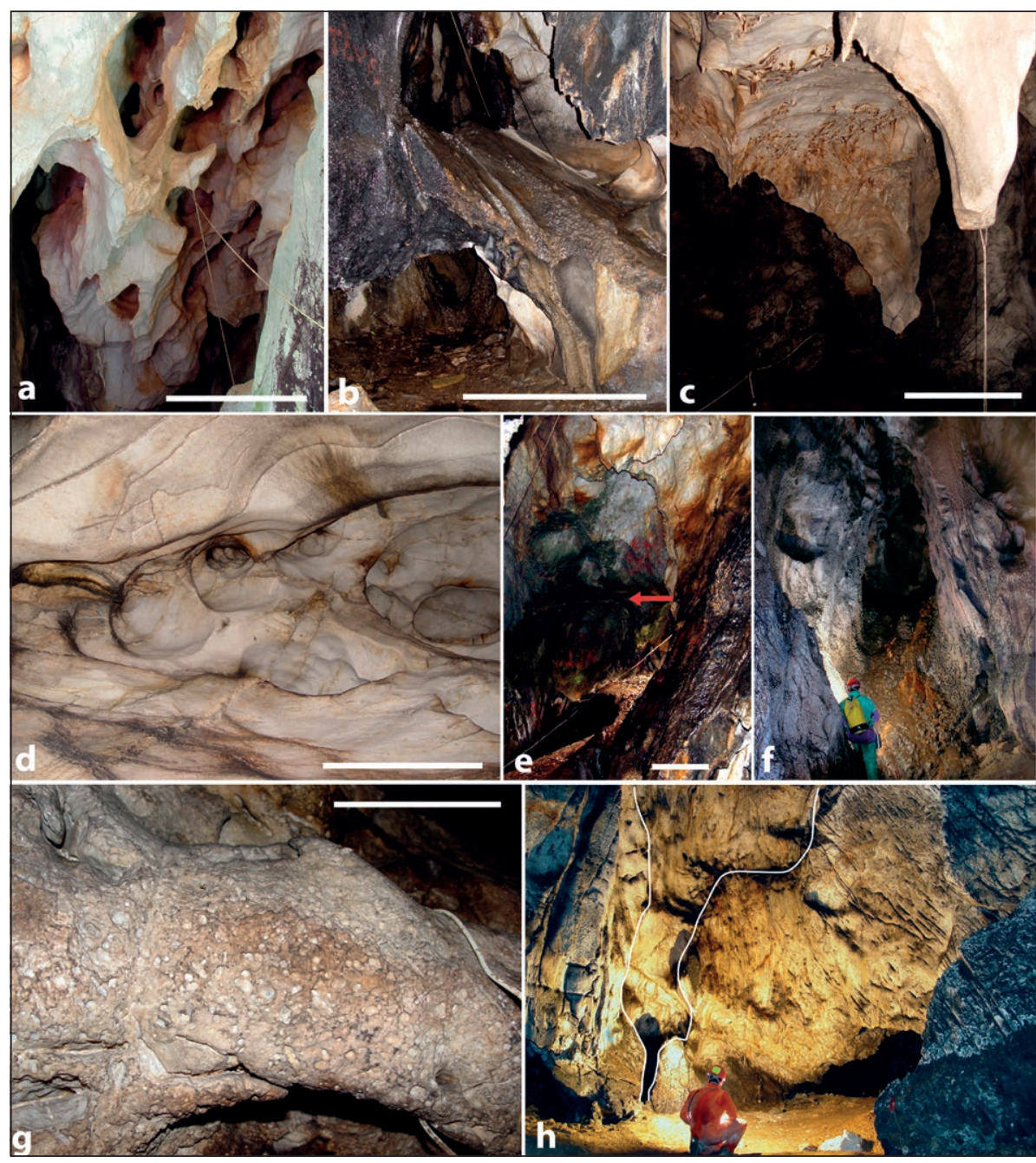

Fig. 4: Dissolution morphology of the Loutra Almopias Cave. a. spongework dissolution; $b$. combination of rock bridge, a window and a bedrock ridge to the background; c. pendants; d. cupolas; e. wall pocket with flat ceiling; f. rising channel; g. small solution pits on the cave-ceiling; $h$. side-wall feeder. Indicative scale bar: $1 \mathrm{~m}: a$, $b, c, e ; 0.5 m$ : $d ; 0.25 m$ : f (Photo: G. Lazaridis). 
about $2 \mathrm{~m}$ lower than the first chamber. The southern passage is a "window" connection of the two chambers. The chamber LAC I (Fig. 5b) is the larger one divided in three areas (LAC Ia, Ib, Ic). Two of these areas are wallpockets of about 4-5 m length (or blind passages) connected to rising channels. The third area is the southern chamber of the cave. LAC Ic presents blind passages to the eastern side, a small passage connecting the chamber to an outlet of the most eastern chamber of the cave (LAC III), cupolas on the ceiling and a 'window' to the southern part where the ceiling exerts downwards. LAC I presents boneyard morphology to the northwestern side of the chamber, cupolas on the ceiling, rising channels (LAC Ia and Ib). A small cupola-shaped chamber is located in the central part of LAC I connected with "windows" and rock ridges (Fig. 5). LAC II chamber is connected to LAC I with window and a rock ridge, and to LAC Ia with a "window" near the cave ceiling (about $10 \mathrm{~m}$ higher the cave-floor). LAC II presents cupolas and large ceiling pendants as well as a massive 'old' flowstone deposited to the eastern blind passage towards the chamber (indicative photos of speleothems are given in Fig. 6). LAC III is of similar morphology with cupolas on the ceiling (Fig. 5). To the western side-wall two feeders have been observed, one of which is the connection to LAC Ic. The chamber terminates to the eastern at a blind pas- sage where eroded sensu lato flowstone observed, similar to that of LAC II. The last two chambers are connected through a "window" passage. Cave-walls present in all chambers pockets nearly flat that grade downward into sloping sidewalls.

Although, the cave walls and ceilings bear many typical dissolution forms, the features on the cave floor are obscured by sediment fill, which is a common feature of the Almopia Speleopark caves. At least in two caves, the Gremos Cave and the Varathron Cave sediment filling of at least 15-20 $\mathrm{m}$ thickness has been removed due to erosion, indicating that a significant vertical cave development can be considered despite the fact that the caves are significantly sediment filled. However the sediment thickness in Loutra Almopias Cave is unknown. A probable feeder close to the eastern sidewall of the chamber LAC I (depicted on Fig. 3), is more than $15 \mathrm{~m}$ in depth but not accessible due to the small dimensions of the opening. This feeder could be connected to a lower cave or passage due to seasonal air wind occurrence, indicating a considerable depth regarding the lateral extent of the cave and the sediment thickness.

The sediments of the cave are detrital in origin, derived from the wider area of the valley (Tsirambides 1998; Kabouroglou \& Chatzitheodorou 1999), with flowstone intercalations.

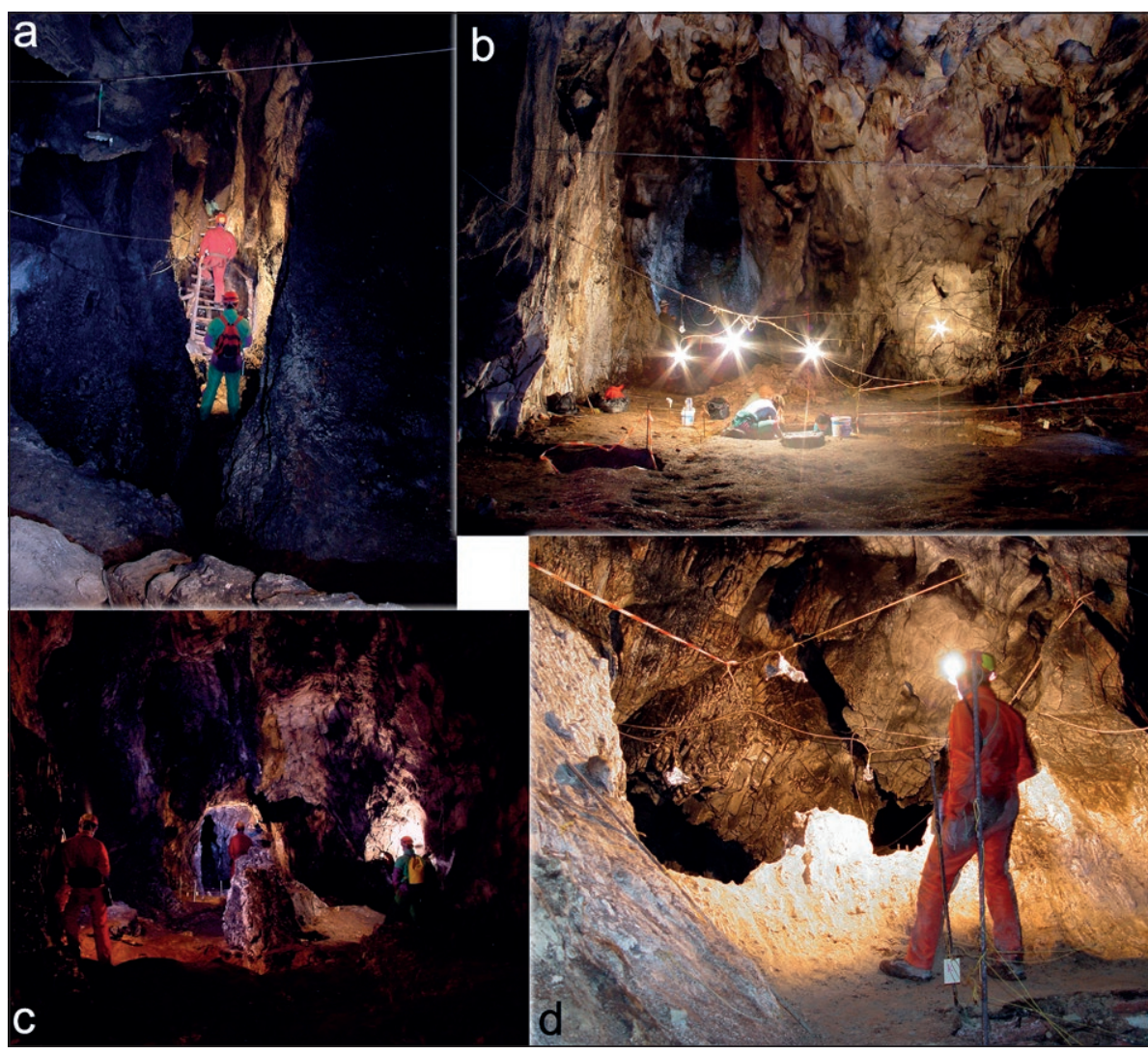

Fig. 5: Loutra Almopias Cave: a. The fissure-like feeder passage that connects the entrance chamber with LAC I chamber of the cave. b. View of the main part of LAC I chamber during excavation. The rising channel of LAC Ic is seen on the left side and the passage to LAC II at right side. c. The LAC III chamber of the cave. d. Rock ridge, partially covered by sediments, in the central chamber LAC I (Photo: G. Lazaridis). 


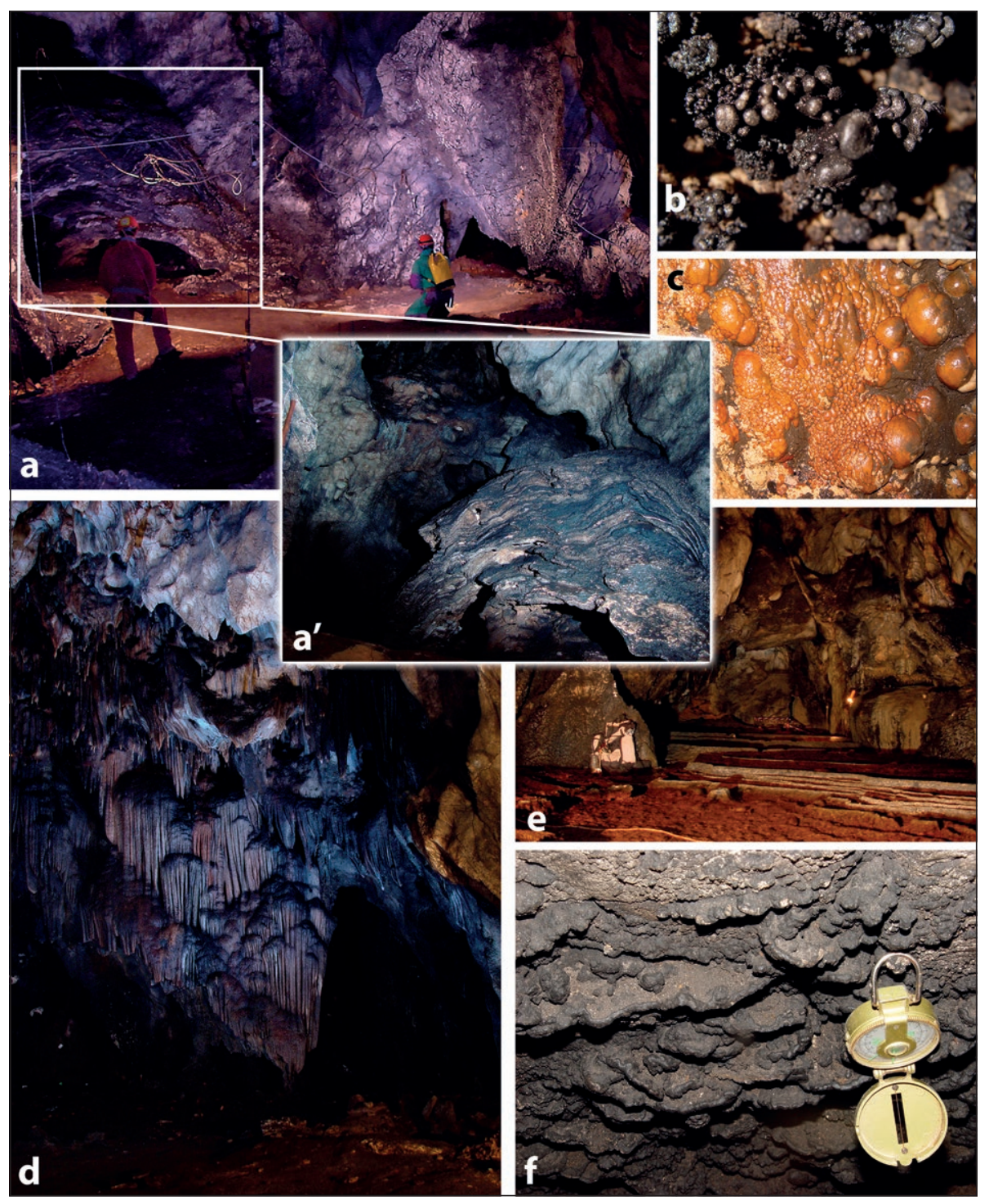

Fig. 6: Speleothems of the Loutra Almopias Cave. a. and a'. "old" flowstone; $b$. cave corals; $c$. cave corals; $d$. stalactites and flowstone; e. rimstone dams; f. rims on vertical side-wall (Photo: G. Lazaridis).

\section{MORPHOLOGY, MINERALOGY AND FLUID INCLUSIONS OF PHREATIC CALCITE FROM THE VARATHRON CAVE}

The Varathron Cave is located at the northern slope of the Thermopotamos valley (Fig. 1). The two lower entrances of the cave are located at $500 \mathrm{~m}$ of altitude and the third one at $520 \mathrm{~m}$. The solutional morphology of the cave is typical for the Almopia Speleopark caves. The higher entrance is connected to the cave with an inclined passage, whose walls are covered by phreatic calcite (subaqueous coatings) forming cave clouds (mammilaries, Text. Fig. 7). Cave clouds are speleothems that are common in hypogenic caves. This speleothem has been reported in caves formed by rising thermal water such as Devil's Hole, Lechuguilla Cave, Carlsbad Caves, Giusti Cave etc.
(Hill \& Forti 1997) and from the hypogene Petralona Cave in Greece (Lazaridis 2009).

The carbonate samples from the speleothems of the Varathron Cave consist mainly of calcite with traces of aragonite (Fig. 8).

The calcite is coarse-grained with the maximum grain size reaching up to $1 \mathrm{~cm}$. The carbonate texture is homeoablastic to weakly heteroblastic, demonstrating grains of almost same size, except some which are smaller. Sometimes a slight grain elongation is observed (Fig. 9a).

The calcite is relatively free of strain and forms 
grains that have sutured boundaries, sometimes embayed or dentate (Fig. 9b). In contrast, a few anhedral, equigranular crystals have straight boundaries, which intersect at $120^{\circ}$ triple junctions (Fig. 9c). Such equilibrium grain configurations are normally present in thermal annealed crystals.

In the present study, fluid inclusions data were obtained from calcite, which comprises the phreatic speleothems in the Varathron Cave. Fluid inclusions were evaluated using fluid inclusion types and fluid inclusion assemblages (FIAs). This evaluation ensures that the results were not influenced by different sizes and shapes of fluid inclusions and it helps to eliminate variable data caused by changes after entrapment (Goldstein \& Reynolds 1994). Fluid inclusions have regular or irregular shapes, and are isolated or are arranged in clusters and planes. Inclusions with negative crystal or rounded to elongated isometric shapes, which are mostly isolated, often occur along crystal faces of calcite (Fig. 9d). They are assumed to be primary in origin with only a few considered as secondary, according to the criteria of Roedder (1984) and Bodnar (2003). Microthermometric measurements were conducted mainly on primary fluid inclusions; inclusions that have been necked down or were secondary in origin were avoided.

Microthermometric results from the fluid inclusions are depicted in Fig. 10. At room temperature, only two phase liquid-vapor inclusions were identified. Inclusions that were analyzed, ranged in diameter between 8 and 95 $\mu \mathrm{m}$ and homogenized into the liquid state. The primary
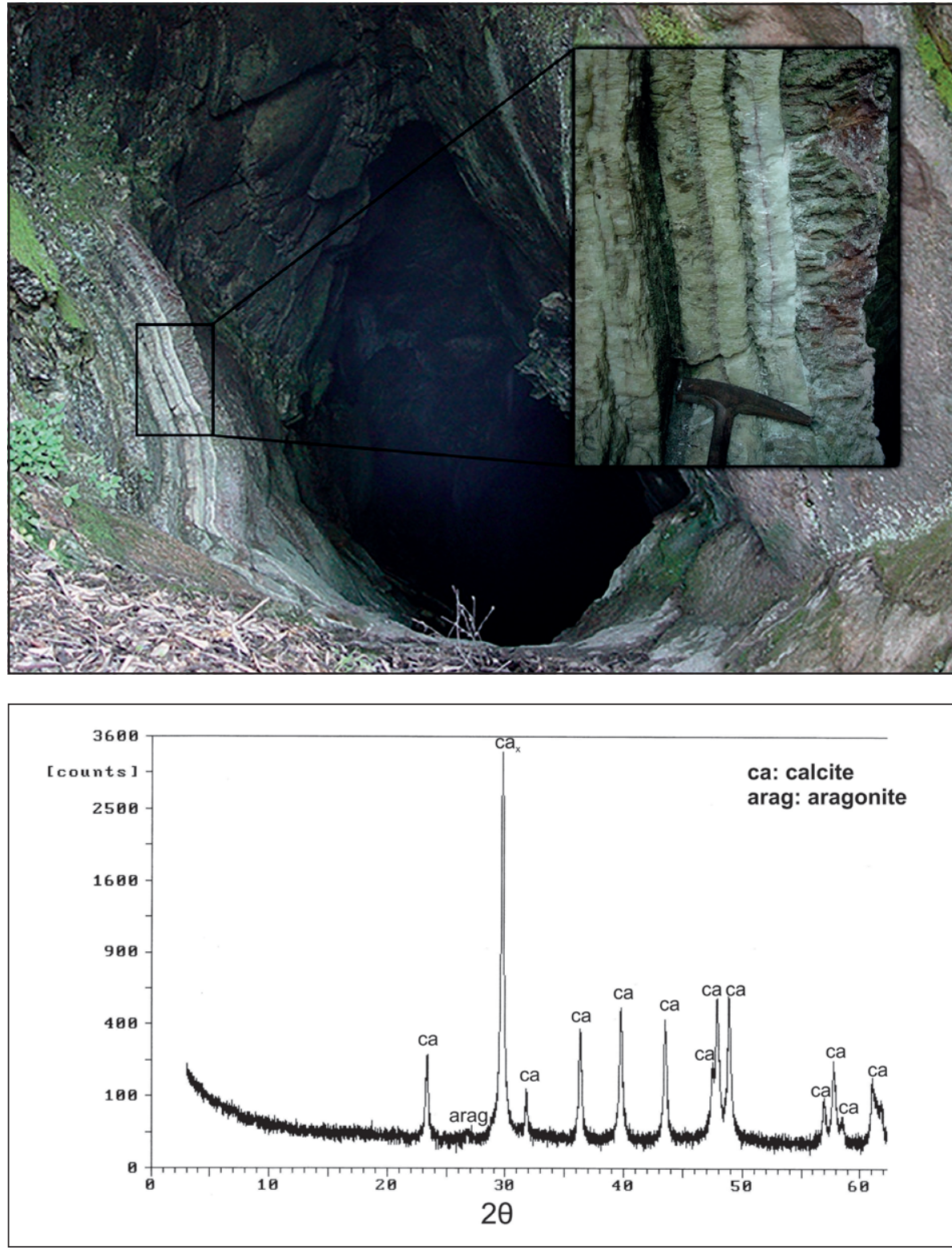

Fig. 7: Entrance of Varathron Cave and the inclined passaged covered by phreatic calcite coatings. Inlet: Close up of sampling site (Photo: G. Lazaridis).
Fig. 8: X-ray diffraction (XRD) diagram of the speleothems at the Varathron cave, consisting mainly of calcite with traces of aragonite. 
fluid inclusions have relatively consistent liquid to vapor ratios (15-20 vol \% vapor). The variability in homogenization temperature data may be due to real variability in the FIAs or to post-entrapment processes such as thermal re-equilibration or undetectable necking-down (Goldstein 2003).

Homogenization temperatures of all but seven of sixty-nine fluid inclusions range from $120^{\circ} \mathrm{C}$ to $189^{\circ} \mathrm{C}$, with a peak around $150{ }^{\circ} \mathrm{C}$ (Fig. 13). The other eight inclusions, possibly secondary, homogenized between 68 ${ }^{\circ} \mathrm{C}$ and $104^{\circ} \mathrm{C}$. Eutectic temperatures (Te) of fluids range from $-20.5^{\circ} \mathrm{C}$ to $-21.5^{\circ} \mathrm{C}$, suggesting that salts in the fluids are dominated by $\mathrm{NaCl}$ (Crawford 1981; Shepherd et al. 1985). The final ice melting temperatures in the same inclusions range from $-0.1{ }^{\circ} \mathrm{C}$ to $-0.6^{\circ} \mathrm{C}$, corresponding to salinities between 0.2 and $1.0 \mathrm{wt} \% \mathrm{NaCl}$ equiv. Many inclusions in calcite can be grouped into FIAs which have a constant liquid to vapor ratios $(\sim 20 \%)$ and variable shapes, clustering along linear trends that do not cross cleavage or growth boundaries. FIAs showed restricted temperature ranges such as $131^{\circ} \mathrm{C}$ to $148^{\circ} \mathrm{C}, 148^{\circ} \mathrm{C}$ to $163{ }^{\circ} \mathrm{C}, 153{ }^{\circ} \mathrm{C}$ to $161^{\circ} \mathrm{C}$ and $154^{\circ} \mathrm{C}$ to $166^{\circ} \mathrm{C}$, showing that the assemblages are true FIAs and, therefore, that these ranges probably represent primary Th. In contrast, the low Th fluid inclusions (Fig. 10) were affected by secondary processes, such as necking-down and leakage.
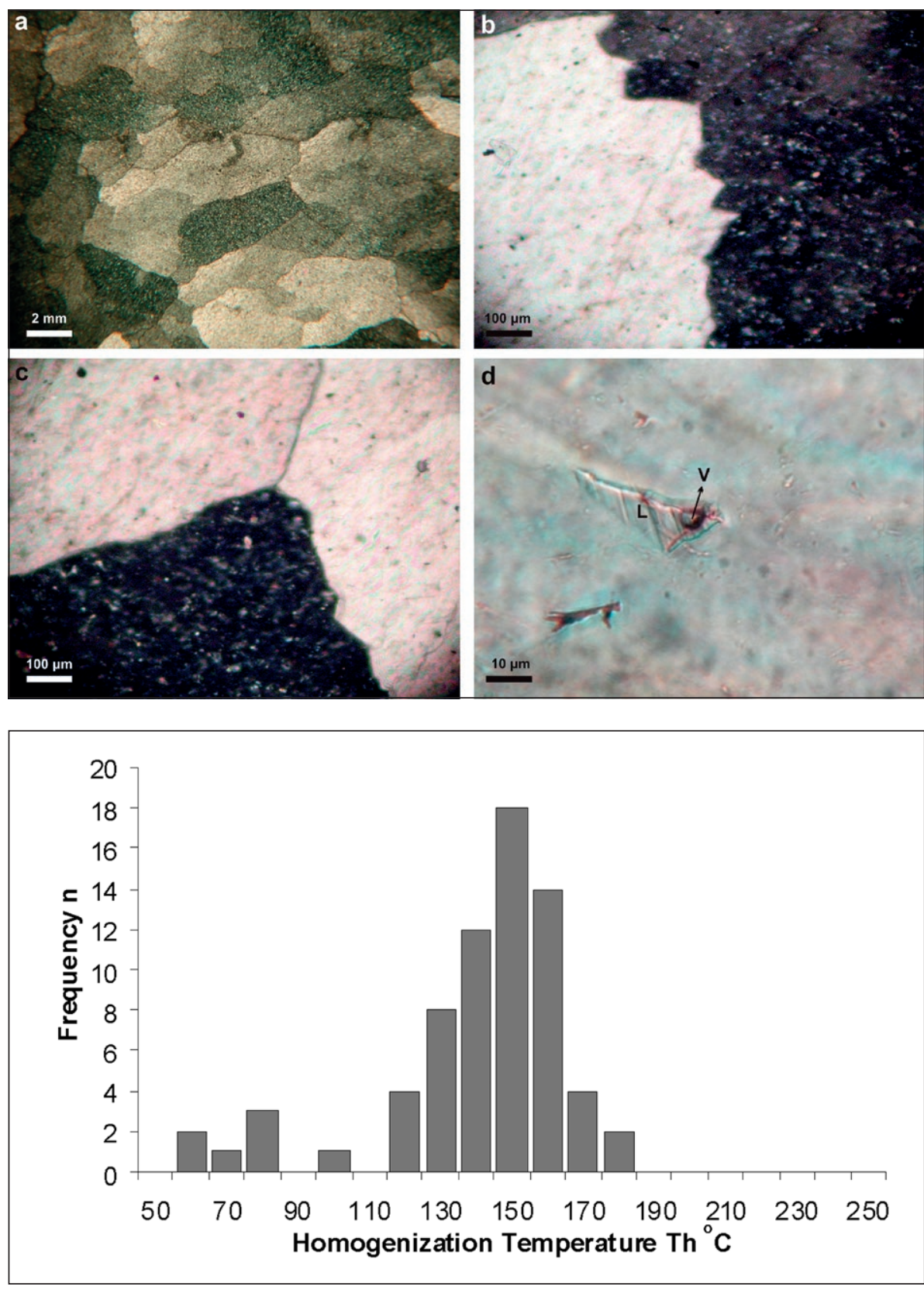

Fig. 9: Microphotographs of the calcites from the Varathron Cave, Almopia Speleopark. a. Elongated calcite crystals; $b$. calcite with sutured boundaries, sometimes embayed or dentate; c. anhedral, equigranular calcite crystals with straight boundaries, which intersect at $120^{\circ}$ triple junctions; $d$. a two-phase aqueous fluid inclusion in calcite from the Varathron Cave. L Liquid, V vapor (Photo: V. Melfos).

Fig. 10: Distribution of the homogenization temperatures of fluid inclusions in calcite from the speleothems of the Varathron Cave. 


\section{CONCLUSIONS}

The Almopia Speleopark comprises a group of caves formed in the Maastrictian limestones of the Pelagonian zone, at the southern foothills of the Voras Mountain. The intrusion of the volcanic rocks and the thermal gradient are related to a number of $\mathrm{Ca}-\mathrm{Mg}-\mathrm{HCO}_{3}$ hot springs, found in the area, with a present temperature up to $37{ }^{\circ} \mathrm{C}$ at the Almopia Speleopark area (Dimopoulos 1990; Patras 1990).

The Loutra Almopias Cave and the Varathron Cave are the most important karst features showing various morphologies, which indicate phreatic conditions. According to Lazaridis (2006) slowly convecting water bodies, possibly related to the hydrothermal field of the area, reacted with the limestones resulting in a complicated cave system. The Loutra Almopias Cave revealed the most of the speleogens that have been recorded in the Almopia Speleopark caves, which are characteristic for hypogene speleogenesis. The fluid inclusion study confirms the hydrothermal-hypogene origin of the Almopia Speleopark caves, proposed in previous work, based on the cave morphology and the geological setting of the area (Lazaridis 2006).
The phreatic calcite crust found in the Varathron Cave, forming cave clouds, is composed of coarsegrained calcite related to hydrothermal fluids. The fluid inclusion study has shown that the calcite has been formed at temperatures ranging between 120 and 189 ${ }^{\circ} \mathrm{C}$, with a peak at $150{ }^{\circ} \mathrm{C}$. The fluids were dominated by $\mathrm{NaCl}$ with very low salinities (0.2-1.0 wt $\% \mathrm{NaCl}$ equiv.), showing probably the incorporation of meteoric waters. This is supported by the $\mathrm{Cl}^{-}$content as well as the relation of the stable isotopes $\left(\mathrm{O}^{18}\right.$ and $\left.\mathrm{D}\right)$ which according to Dotsika et al. (2006) indicate a strong contribution of meteoric water.

Some parts of the caves were subjected to minor modifications by a second phase of speleogenesis that is related to the geomorphological evolution of the area, which comprises mountain uplift, down-cutting erosion and the invasion of the Thermopotamos Stream into the caves. The latter, re-sculptured some cave walls under turbulent flow conditions and deposited detrital sediments as well as the fossils found in the Loutra Almopias Cave.

\section{ACKNOWLEDGEMENTS}

We thank Professor Stephan Kempe, University of Darmstadt, Germany, for his thorough and helpful discussions on the caves' morphology. We also thank the reviewers of an early version L. Plan, P. Voudouris, A. Klimchouk and P. Audra for their fruitful comments and suggestions.

\section{REFERENCES}

Audra, P., Mocochain, L., Bigot, J.Y. \& J.C. Nobécourt, 2009a: Morphological indicators of speleogenesis: hypogenic speleogenesis.- In: Klimchouk, A. \& D. Ford (eds.) Hypogene Speleogenesis and Karst Hydrogeology of Artesian Basins. Institute of Speleology and Karstology, pp. 17-22, Simferopol.

Audra, P., Mocochain, L., Bigot, J.Y. \& J.C. Nobecourt, 2009b: Hypogene cave patterns.- In: Klimchouk, A. \& D. Ford (eds.) Hypogene Speleogenesis and Karst Hydrogeology of Artesian Basins. Institute of Speleology and Karstology, pp. 23-32, Simferopol.

Bodnar, R.J., 2003: Introduction to fluid inclusions.- In: Samson, I. et al. (eds.) Fluid inclusions: analysis and interpretation. Short course series, Vol. 32, Mineralogical Association of Canada, pp. 1-8, Québec.

Bögli, A., 1978: Karsthydrographie und Physische Speläologie.- Springer-Verlag, pp. 292, Heidelberg.

Brown, P.E., 1989: FLINCOR: A microcomputer program for the reduction and investigation of fluid inclusion data.- American Mineralogist, 74, 11, 1390-1393.

Chatzidimitriadis, E.A., 1974: Die Problematik der Erwärmung von Thermalquellen und ihre Zusammenhänge zu den geologisch-tektonischen Verhältnissen ihrer Umgebungen anhand von zwei Beispielen, nämlich der Heilquelle von Ano Loutraki bei Aridea West Mazedonien und von Trajanoupolis West Thrakiens.- Scientific Annals, Faculty of Physics and 
Mathematics, Aristotle University of Thessaloniki, $14,113-128$.

Chatzopoulou, K., Vasileiadou, A., Koliadimou, K., Tsoukala, E., Rabeder, G. \& D. Nagel, 2001: Preliminary report on the Late Pleistocene small mammal fauna from Loutraki "Bear Cave" (Pella, Macedonia, Greece).- Cadernos do Laboratorio Xeoloxico de Laxe, 26, 485-495.

Crawford, M.L., 1981: Phase equilibria in aqueous fluid inclusions.- In: Hollister, L.S. \& M.L. Crawford (eds.) Short course in fluid inclusions: applications to petrology. Mineralogical Association of Canada, pp. 75-100, Québec.

De Waele, J., Audra, P., Madonia, G., Vattano, M., Plan, L., D'Angeli, I.M., Bigot, J.Y. \& J.C. Nobécourt, 2016: Sulfuric acid speleogenesis (SAS) close to the water table: Examples from southern France, Austria, and Sicily.- Geomorphology, 253, 452-467. http:// dx.doi.org/10.1016/j.geomorph.2015.10.019

Dimopoulos, G., 1990: Hydrogeological and hydrochemical characteristics of thermal mineral waters of Greece.- In: Proceedings of the 2nd Symposium of mineral waters, 41-57. Thessaloniki, (in Greek).

Dotsika, E., Poutoukis, D., Michelot, J.L. \& W. Kloppmann, 2006: Stable isotope and chloride, boron study for tracing sources of boron contamination in groundwater: boron contents in fresh and thermal water in different areas in Greece.- Water, Air, and Soil Pollution, 174, 19-32. https://doi.org/10.1007/ s11270-005-9015-8

Dublyansky, Y.V., 2013: Karstification by geothermal waters.- In: Shroder, J. \& A. Frumkin, (eds) Treatise on Geomorphology. Volume 6, Academic Press, pp. 57-71, San Diego.

Dublyansky, Y.V. 2014: Hypogene speleogenesis - discussion of definitions.- In: Klimchouk, A. et al. (eds.) Hypogene Cave Morphologies. Special Publication 18, Karst Waters Institute, pp.1-3, Leesburg.

Eleftheriadis, G., 1977: Study of the volcanic rocks in South Almopia.- PhD Thesis, Aristotle University of Thessaloniki, pp.173.

Ford, C.D., 2000: Speleogenesis under unconfined settings.- In: Klimchouk, B.A. et al. (eds.) Speleogenesis. Evolution of karst aquifers. National Speleological Society, pp. 319-324, Huntsville.

Goldstein, R., 2003: Petrographic analysis of fluid inclusions.- In: Samson, I.M. et al. (eds.) Fluid inclusions: analysis and interpretation. Short course series, Vol. 32, Mineralogical Association of Canada, pp. 9-53, Québec.

Goldstein, R.H. \& T.J. Reynolds, 1994: Systematics of fluid inclusions in diagenetic minerals.- SEPM Short
Course 31, SEPM Society for Sedimentary Geology, pp.199, Tulsa.

Hill, C.A. \& P. Forti, 1997: Cave minerals of the world. 2nd ed., National Speleological Society, pp. 463, Huntsville.

Kabouroglou, E. \& T. Chatzitheodorou, 1999: Geomorphological changes and sedimentation of the A cave (Agiasma) of Loutraki (Pella, Macedonia, Greece).In: Proceedings of the 5th Congress of the Greek Geographical Society, 83-93, Athens (in Greek).

Kempe, S., Brandt, A., Seeger, M. \& F. Vladi, 1975: "Facetten" and "Laugdecken", the typical morphological elements of caves developing in standing water.Annales de Spéléologie, 30, 4, 705-708.

Klimchouk, A.B., 2007: Hypogene Speleogenesis: Hydrogeological and Morphogenetic Perspective.- Special Paper no.1, National Cave and Karst Research Institute, pp. 106, Carlsbad.

Klimchouk, A.B., 2009: Morphogenesis of hypogenic caves.- Geomorphology, 106, 1-2, 100-117. https:// doi.org/10.1016/j.geomorph.2008.09.013

Klimchouk, A.B., 2018: Advances in understanding of hypogene karst.- In: Stafford, K. \& G. Veni (ed.) Hypogene Karst in Texas. Texas Speleological Survey, pp. 1-122, Austin, TX, USA.

Klimchouk, A.B., Sasowsky, I.D., Mylroie, J., Engel, S.A. \& A. Summers-Engel (eds.), 2014: Hypogene Cave Morphologies. Special publication 18, Selected papers and abstracts of the symposium, $2^{\text {nd }}-7^{\text {th }}$ February 2014, San Salvador Island, Bahamas. Karst Waters Institute, pp.103, Leesburg.

Klimchouk, A., Palmer, A.N., De Waele, J., Auler, A.S. \& P. Audra (eds.), 2017: Hypogene Karst regions and caves of the world.- Springer, pp. 911, Cham.

Kolios, N., Innocenti, F., Manetti, P., Peccerillo, A. \& O. Giulani, 1980: The Pliocene volcanism of the Voras Mts (Central Macedonia, Greece).- Bulletin Volcanologique, 43, 3, 553-568. https://doi.org/10.1007/ BF02597692

Lauritzen, S.E. \& J. Lundberg, 2000: Solutional and erosional morphology.- In: Klimchouk, B.A. et al. (eds.) Speleogenesis. Evolution of karst aquifers. National Speleological Society, pp. 408-426, Huntsville.

Lazaridis, G., 2005: Speleological research in the Loutra Arideas area (Macedonia, Greece).- Neue Forschungen zum Höhlenbären in Europa, 45, 57-64.

Lazaridis, G., 2006: Almopia Speleopark (Pella, Macedonia, Greece): Morphology-Speleogenesis of the caves.- Scientific annals, School of geology, Aristotle University of Thessaloniki (AUTH), Special Volume 98, 33-40.

Lazaridis, G., 2009: Petralona Cave: Morphological analysis and a new perspective on its speleogenesis.- In: 
Klimchouk, A. \& D.C. Ford (eds.) Hypogene Speleogenesis and Karst Hydrogeology of Artesian Basins. Special Paper 1, Ukrainian Institute of Speleology and Karstology, pp. 233-239, Simferopol.

Lazaridis, G., 2017: Hypogene Speleogenesis in Greece.In: Klimchouk, A. et al. (eds.) Hypogene Karst Regions and Caves of the World. Springer, pp. 225-239, Cham.

Lunberg, J., 2005: Karren.- In: Culver, D.C. \& W.B. White (eds.) Encyclopedia of caves. Elsevier Inc, pp. 315321, Amsterdam.

Mercier, J.J., Vergely, P. \& A. Galeos, 1988: Geological map of Greece, Arnissa sheet, scale 1:50.000.- Athens.

Mountrakis, D., 1976: Contribution to the knowledge of the geology of the north boundary of the Axios and Pelagonian zones in the K. Loutraki-Orma area (Almopia).- PhD Thesis, Aristotle University of Thessaloniki, pp. 164.

Osborne, R.A.L., 2004: The troubles with cupolas.- Acta carsologica, 33, 2, 9-36. https://doi.org/10.3986/ ac.v33i2.289

Palmer, A.N. 2000: Hydrogeologic control of cave patterns.- In: Klimchouk, B. A. et al. (eds.) Speleogenesis. Evolution of karst aquifers. National Speleological Society, pp. 77-90, Huntsville.

Palmer, A.N., 2005: Passage growth and development.In: Culver, D.C. \& W.B. White (eds.) Encyclopedia of caves. Elsevier Inc, pp. 440-444, Amsterdam: Elsevier.

Palmer, A.N., 2007: Cave Geology.- Cave Books, pp. 454, Dayton.

Pappa, S., Tsoukala, E., Lazaridis, G. \& G. Rabeder, 2005: Milk teeth of Quaternary carnivores from Northern Greek Caves.- Neue Forschungen zum Höhlenbären in Europa, 45, 169-182.

Patras, D., 1990: Hydrogeological and hydrochemical research of the thermometallic springs in the area of Loutraki, Aridea (Loutra Pozar). In: Proceedings of the 2nd Symposium of mineral waters, 167-185, Thessaloniki, (in Greek).

Psilovikos, A. \& E. Kanetsis, 1989: Distribution and paleogeographic significance of the planation surfaces on the mountain blocks of the Pelagonian massif.Bulletin of the Geological Society of Greece, 23, 1, 279-287.

Rabeder, G., Hofreiter, M., Nagel, D. \& G. Withalm, 2004: New taxa of Alpine Cave Bears (Ursidae, Camivora).- Cahiers Scientifiques, 2, 49-67.

Roedder, E., 1984: Fluid Inclusions.- Reviews in Mineralogy, 12, 1-646.

Shepherd, T., Rankin, A. \& D. Alderton, 1985: A practical guide to fluid inclusion studies.- Blackie and Son, pp. 239, Glasgow.
Temovski, M., Audra, P., Mihevc, A., Spangenberg, J.E., Polyak, V., McIntosh, W. \& J.Y. Bigot, 2013: Hypogenic origin of Provalata Cave, Republic of Macedonia: a distinct case of successive thermal carbonic and sulfuric acid speleogenesis.- International Journal of Speleology, 42, 3, 235-246. https://dx.doi. org/10.5038/1827-806X.42.3.7

Temovski, M., 2017: Hypogene Karst in Macedonia.In: Klimchouk, A. et al. (eds.) Hypogene Karst Regions and Caves of the World. Springer, pp. 241-256, Cham.

Tsirambides, A., 1998: Study of floor sediments from the Agiasma Cave of Loutraki, Pella (Macedonia, Greece).- Bulletin of the Geological Society of Greece, 34, 339-349. (in Greek).

Tsoukala, E., 1994: Bärenreste aus Loutraki (Mazed., Griechen.).- In: $2^{\text {nd }}$ Höhlenbären Symposium, $15^{\text {th }}$ $18^{\text {th }}$ September 1994, Corvara.

Tsoukala, E. \& G. Rabeder, 2005: Cave bears and Late Pleistocene associated faunal remains from Loutra Arideas (Pella, Macedonia, Greece). 15 years of research. - Neue Forschungen zum Höhlenbären in Europa, 45, 225-236.

Tsoukala E., Rabeder, G. \& S. Verginis, 1998: Ursus spelaeus and associated faunal remains from Loutraki (Pella, Macedonia, Greece). Excavations of 1996. Geological and geomorphological approach.- In: Proceedings of the 4th International Höhlenbären Symposium, Velenje.

Tsoukala E., Rabeder, G. \& S. Verginis, 2001: Ursus spelaeus and Late Pleistocene associated faunal remains from Loutraki (Pella, Macedonia, Greece). Excavations of 1999.- Cadernos do Laboratorio Xeoloxico de Laxe, 26, 441-446.

Tsoukala, E., Chatzopoulou, K., Rabeder, G., Pappa, S., Nagel, D. \& G. Withalm, 2006: Paleontological and stratigraphical research in Loutra Arideas Bear Cave (Almopia Speleopark, Pella, Macedonia, Greece).Scientific Annals, School of Geology, Aristotle University (AUTH), special volume, 98, 41-67.

Vougioukalakis, G., 2002: Petrological, geochemical, volcanological study of the Almopias Pliocene volcanic formations and their correlation with the geothermal manifestations in the area.- Ph.D Thesis, Aristotle University of Thessaloniki, pp. 303.

White, B.W. \& H. G. Deike III, 1989: Hydraulic geometry of cave passages.- In: White, W. \& E. White (eds.) Karst Hydrology. Concepts from the Mammoth Cave Area. Van Nostrand Reinhold, pp. 223-258, New York. 